\title{
Systematic Review of the Relationship between Amyloid- $\beta$ Levels and Measures of Transgenic Mouse Cognitive Deficit in Alzheimer's Disease
}

\author{
Avery M. Foley, Zeena M. Ammar, Robert H. Lee and Cassie S. Mitchell* \\ Department of Biomedical Engineering, Georgia Institute of Technology and Emory University, Atlanta, GA, USA
}

Accepted 23 September 2014

\begin{abstract}
Amyloid- $\beta$ (A $\beta$ ) is believed to directly affect memory and learning in Alzheimer's disease (AD). It is widely suggested that there is a relationship between $A \beta_{40}$ and $A \beta_{42}$ levels and cognitive performance. In order to explore the validity of this relationship, we performed a meta-analysis of 40 peer-reviewed, published AD transgenic mouse studies that quantitatively measured $A \beta$ levels in brain tissue after assessing cognitive performance. We examined the relationship between $A \beta$ levels $\left(A \beta_{40}, A \beta_{42}\right.$, or the ratio of $A \beta_{42}$ to $A \beta_{40}$ ) and cognitive function as measured by escape latency times in the Morris water maze or exploratory preference percentage in the novel object recognition test. Our systematic review examined five mouse models (Tg2576, APP, PS1, 3xTg, APP(OSK)-Tg), gender, and age. The overall result revealed no statistically significant correlation between quantified $A \beta$ levels and experimental measures of cognitive function. However, enough of the trends were of the same sign to suggest that there probably is a very weak qualitative trend visible only across many orders of magnitude. In summary, the results of the systematic review revealed that mice bred to show elevated levels of $A \beta$ do not perform significantly worse in cognitive tests than mice that do not have elevated $A \beta$ levels. Our results suggest two lines of inquiry: 1) A $\beta$ is a biochemical "side effect" of the AD pathology; or 2) learning and memory deficits in AD are tied to the presence of qualitatively "high" levels of $A \beta$ but are not quantitatively sensitive to the levels themselves.
\end{abstract}

Keywords: Amyloid- $\beta$, cognitive deficit, memory, Morris water maze, mouse model, novel object recognition, $\operatorname{Tg} 2576$

\section{INTRODUCTION}

Amyloid- $\beta(\mathrm{A} \beta)$ has been the most cited probable causative factor in Alzheimer's disease (AD) since the identification of $\mathrm{A} \beta$ in 1984 [1]. Therefore, much research and focus within the AD community has been devoted to analyzing the relationship and possible role $\mathrm{A} \beta$ plays in the onset and progression of $\mathrm{AD}$ [2]. One of the main theories in AD causation is the Amyloid Cascade Hypothesis, which proposes that $A \beta$ formation leads to a series of neurotoxic events that eventually

\footnotetext{
*Correspondence to: Cassie S. Mitchell, PhD, Georgia Institute of Technology, 313 Ferst Drive, Atlanta, GA 30332, USA. Tel.: +1 404276 8475; E-mail: cassie.mitchell@bme.gatech.edu.
}

lead to cell death [3]. As a result, significant amounts of research have been performed analyzing the relationship between $A \beta_{42}$ and $A \beta_{40}$ levels and cognitive performance in transgenic mice, and numerous articles have claimed a significant correlation between increased $A \beta$ levels and cognitive decline (e.g., [4-8]).

One of the most common methods of experimentally assessing $\mathrm{A} \beta$ in $\mathrm{AD}$ is to subject transgenic $\mathrm{AD}$ mice to behavioral tests that assess memory/learning and then subsequently measure $A \beta$ levels posttest [9]. $\operatorname{Tg} 2576$ is the most commonly used mouse model for this analysis as it shows elevated levels of $A \beta$ at a young age [10]. The Morris water maze (MWM) is one of the most common memory/learning test as escape latency time in the maze is said to be correlated with spatial 
learning and memory [11]. Another common test is the novel object recognition (NOR) test, which tests the recognition memory of mice [12].

The ratio of $A \beta_{42}$ to $A \beta_{40}$ is considered just as significant, if not a better criteria for $\mathrm{AD}$ onset, as the ratio considers inter-individual variations in total amyloid load, whereas absolute values can have higher variance between individual test subjects [13]. Furthermore, $A \beta_{42}$ is believed to be much more neurotoxic and thus, more connected to cell death than $A \beta_{40}$; in fact, $A \beta_{40}$ has even been shown to inhibit $A \beta_{42}$ oligomerization [14]. Therefore, a higher percentage of $A \beta_{42}$ is deemed more correlative of AD onset under the Amyloid Cascade hypothesis [14]. Together, MWM or NOR results, in combination with $A \beta_{42}$ to $A \beta_{40}$ ratios in tested $\operatorname{Tg} 2576$ mice, provide a way of analyzing the correlation between $A \beta$ and spatial memory and learning deficiencies associated with onset and progression of AD [15].

However, recent articles have shown evidence that challenges the Amyloid Cascade Hypothesis, suggesting that $A \beta$ is not the causative factor in $A D$ onset (e.g., [16-20]). The goal of this study was to examine the potential relationship between experimental $A \beta$ levels and mouse cognitive function. We perform a meta-analysis of 40 existing studies that quantitatively examined the $A \beta_{42}$ to $A \beta_{40}$ ratio in transgenic mouse brain tissue in relation to MWM escape latency or NOR exploratory preference.

\section{MATERIALS AND METHODS}

We performed a systematic review of the transgenic mouse literature to examine the potential correlation between brain tissue measured $A \beta$ levels and experimental measures of mouse cognitive function as described in detail below.

\section{Inclusion and Exclusion Criteria}

Inclusion was based on Key term searches in PubMed to find potentially relevant publications. The terms were "Alzheimer's Disease" (including all MESH equivalents), mouse model (e.g., Tg2576, APP, etc.; see below), and cognitive deficit measure (e.g., Morris water maze; see below). General exclusion criteria were English only and the presence of quantitative data for both $A \beta_{40}$ and $A \beta_{42}$ levels found in the brain. Additional, test-specific exclusion criteria are listed below for each cognitive deficit test.

\section{Mouse Model Descriptions}

$\operatorname{Tg} 2576$

The Tg2576 mouse model expresses the human APP695 isoform with double mutation K670N, M671 L also known as hAPPSw via the hamster prion promoter [9]. As a result this mouse exhibits levels of human amyloid- $\beta$ protein precursor (A $\beta P P$ ) six times greater than that of mouse $A \beta P P$ levels [9]. In addition the mice show higher levels of $A \beta_{40}$ and $A \beta_{42}$ [9]. $A \beta$ deposits begin at 9 months of age [9].

\section{$A P P$}

This model expresses hAPPSw and APP751 isoform under the control of the murine Thy 1 promoter [21]. As a result this mouse exhibits levels of human A $\beta P P$ seven times greater than that of mouse A $\beta P P$ levels [21]. A $\beta$ plaques begin at 6 months of age [21].

\section{APP $(O S K)-T g$}

The APP(OSK)-Tg model expresses A $\beta P P$ harboring the Osaka (E693 $\Delta$ ) mutation [22]. These mice exhibit intraneuronal A $\beta$ oligomers and memory impairment from 8 months of age [22].

\section{PS1}

These mice express human presenilin with mutation M146 L or M146 V via the PDGF- $\beta$ promoter [23]. This results in higher levels of endogenous mouse $\mathrm{A} \beta_{1-42 / 43}$ [23].

$3 x T g$

This triple-transgenic model of AD exhibits both $\mathrm{A} \beta$ and tau pathology, and mimics human AD [24].

\section{Cognitive Deficit Test Descriptions}

\section{Morris Water Maze}

The MWM tests the spatial reference memory of mice [25]. The mice are usually trained to search for a hidden platform using visual cues surrounding the maze [25]. After the final day of training and usually a 24-hour waiting period, the mice are inserted once again into the maze and the time taken to find the hidden platform is measured [25]. Test-specific exclusion criteria were visible platform (i.e., use of hidden platform was a requirement), allowing the mouse to stay within the maze for more than 60 seconds, and lack of escape latency time assessment. 


\section{Novel Object Recognition}

NOR tests the recognition memory of mice [12]. The mice are shown two objects and allowed to explore the objects [12]. One of the original two objects is then replaced with a novel object [12]. Usually after 4 hours and 24 hours the mouse is allowed to explore the new object set up [12]. The time the mice spend with the old and the new object is recorded and if the mouse spent more time exploring the novel object then it recognizes the object as different from the original set up [12]. Thus the exclusion criterion was using an assessment metric other than exploratory preference percentage.

\section{Analysis}

Some papers presented averaged assessments while others presented all data from multiple trials. Consequently, we averaged within-paper multi-trial data so that all papers would be given equivalent weighting in the review.

The data were divided into the following mouse age groups: 6-11 months, 12-14 months, and 15-20 months. Separately, the data was broken down into groups by gender.

Prior to conducting a statistical analysis of significance, the distribution of the data was first determined. Through the analysis of normal probability plots of the data, it was found that the data fell into a normal distribution. Statistical significance was subsequently assessed with an F-test of the least-squares regression line of cognitive deficit test metric versus log of $A \beta$ levels or $\log$ of $A \beta_{42} / A \beta_{40}$ ratios. Note that the $\log$ of $A \beta$ level was utilized due to the large variation of $A \beta$ level magnitudes among the pooled studies. Despite the large number of examined correlations, a very generous $p$-value $<0.05$ was used as the threshold for potential significance based on the ultimate findings.

\section{RESULTS}

A total of 40 peer-reviewed, published scientific articles met the study inclusion criteria. From these articles, a total of 230 data points were extracted to assess the relationship between $\mathrm{A} \beta$ level and AD transgenic mouse cognitive performance. The data was categorized and analyzed by mouse type, A $\beta$ type, $\mathrm{A} \beta$ solubility, gender, age, and cognitive test utilized (see Table 1). Raw soluble and insoluble $A \beta$ levels $\left(A \beta_{40}\right.$ and $\left.A \beta_{42}\right)$ as well as $A \beta_{42}$ to $A \beta_{40}$ ratios were examined for each category shown.

We began by examining the data for the raw $A \beta_{42}$ and $A \beta_{40}$ levels. MWM escape latency was plotted versus both the log of soluble and insoluble $A \beta_{42}$ and $A \beta_{40}$ levels for all of the $\mathrm{Tg} 2576$ transgenic mouse studies. As shown in Fig. 1, raw A $\beta$ levels vary greatly in magnitude among the data extracted from 21 different articles. An assessment of the relationship of MWM escape latency versus log of insoluble levels of $\mathrm{A} \beta_{40}$ result in a $r^{2}$ value of 0.049 and a $p$-value of 0.24 , and the log of insoluble levels of $\mathrm{A} \beta_{42}$ result in a $r^{2}$ value of 0.125 and a $p$-value of 0.043 . Similarly, the $\log$ of soluble levels of $\mathrm{A} \beta_{40}$ result in a $r^{2}$ value of 0.0017 and a $p$-value of 0.80 , while the log of soluble levels of $\mathrm{A} \beta_{42}$ result in a $r^{2}$ value of 0.027 and a $p$-value of 0.281 . In summary, these statistical results reveal that only insoluble $A \beta_{42}$ concentration was potentially significant. Note, however, three of the four plots show the same trend toward increasing escape latency across four or five orders of magnitude of concentration.

Next, we examined the MWM escape latency versus the $A \beta_{42} / A \beta_{40}$ ratio, since the ratio is thought to be a better assessment measure than the raw $A \beta$ levels [13]. Figure 2 shows the overall results of the meta-analysis for both the soluble and insoluble data points in $\mathrm{Tg} 2576$ mice. The effect of the $\log$ of insoluble $A \beta$ ratio on average escape latency in the MWM was found to have an $r^{2}$ value of 0.118 and a $p$-value of 0.0625 , showing that there was no correlation between soluble $A \beta_{42}$ to $A \beta_{40}$ ratio and escape latency results. Results for log of soluble $A \beta$ ratio were similarly non-correlative with an $r^{2}$ value of 0.039 and a $p$-value of 0.206 . However both soluble and insoluble weakly trend toward higher ratios corresponding to lower escape latencies.

To assess the possible effects of gender and age, we split the full $\mathrm{Tg} 2576$ data set into different corresponding groups. Figure 3 shows MWM escape latency versus the log of $A \beta_{42} / A \beta_{40}$ ratio for $T g 2576$ separated by age and gender of the mice. The 6-11 month group has an $r^{2}$ value of 0.31 and a $p$-value of 0.33 ; the 12-14 month group has an $r^{2}$ value of 0.001 and $p$-value of 0.88 , and the 15-20 month group has an $r^{2}$ value of 0.093 and a $p$-value of 0.25 . These results again fail to reach our threshold for statistical correlation between MWM escape latency and the $A \beta_{42} / A \beta_{40}$ ratio. The results for the female-only $\mathrm{Tg} 2576$ groups are similarly non-correlative. The female data set has an $r^{2}$ value of 0.02 and a $p$-value of 0.6. There were an insufficient number of male-only studies to perform a correlation analysis.

Finding no correlation between $A \beta_{42} / A \beta_{40}$ ratio and MWM latency in the Tg2576 mouse studies, we subsequently examined other mouse models for a possible correlation, including the APP(OSK)-Tg, PS1, 3xTg, and APP. However, as shown in Fig. 4, there is no 
Table 1

Transgenic mouse studies included in the systematic review

\begin{tabular}{|c|c|c|c|c|c|c|}
\hline Model & Type & $\begin{array}{c}\text { Included } \\
\text { articles }\end{array}$ & $\begin{array}{c}\text { Soluble } \\
\text { data points }\end{array}$ & $\begin{array}{c}\text { Insoluble } \\
\text { data points }\end{array}$ & $\begin{array}{c}\text { Total } \\
\text { data points }\end{array}$ & Reference \\
\hline \multicolumn{7}{|c|}{ Morris water maze } \\
\hline \multirow[t]{6}{*}{$\operatorname{Tg} 2576$} & All & 21 & 86 & 63 & 149 & [34-55] \\
\hline & Female & 8 & 28 & 20 & 48 & {$[35,41,43,45,48-51]$} \\
\hline & Male & 1 & 4 & 4 & 8 & {$[40]$} \\
\hline & 6-11 Mo. & 4 & 9 & 6 & 15 & [34-37] \\
\hline & 12-14 Mo. & 10 & 47 & 35 & 82 & {$[38-47]$} \\
\hline & 15-20 Mo. & 8 & 32 & 22 & 54 & {$[48-55]$} \\
\hline App & All & 3 & 10 & 8 & 18 & {$[56-58]$} \\
\hline PS1 & All & 5 & 8 & 14 & 22 & [59-62] \\
\hline APP(OSK) & All & 1 & 4 & 4 & 8 & {$[22]$} \\
\hline $3 x \mathrm{Tg}$ & All & 2 & 8 & 6 & 14 & {$[63,64]$} \\
\hline \multicolumn{7}{|c|}{ Novel object recognition } \\
\hline $\operatorname{Tg} 2576$ & All & 8 & 11 & 8 & 19 & [65-72] \\
\hline
\end{tabular}
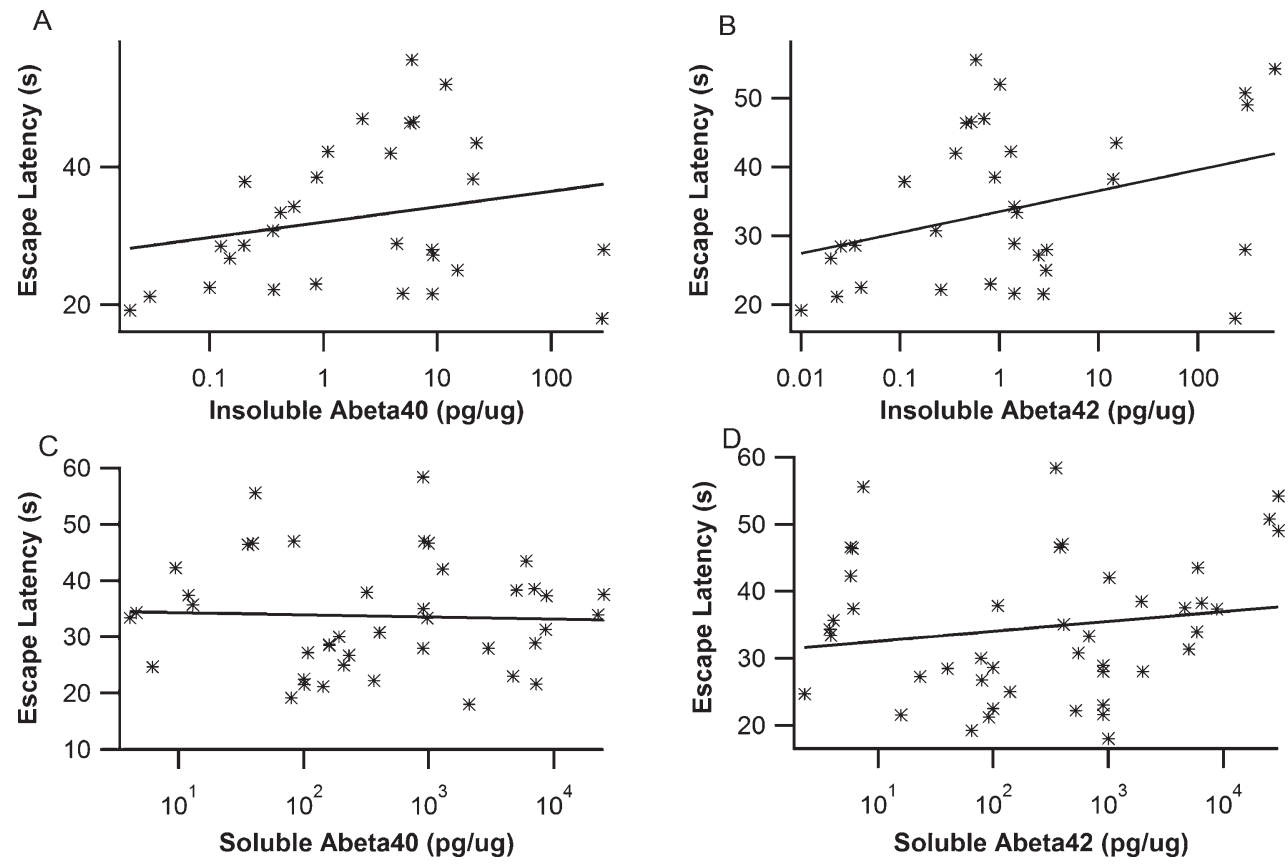

Fig. 1. The log of raw $A \beta_{40}$ and $A \beta_{42}$ soluble and insoluble levels per area of tissue in the brain is plotted versus Morris water maze escape latency in Tg2576 mice. Only the insoluble level of $A \beta_{42}$ was found to be significantly correlated with Morris water maze escape latency. No correlation was found between escape latency and insoluble $A \beta_{40}$, soluble $A \beta_{40}$, or soluble $A \beta_{42}$. A) Insoluble levels of $A \beta_{40}, r^{2}=0.049$, $p$-value $=0.24$. B) Insoluble levels of $\mathrm{A} \beta_{42}, r^{2}=0.125, p$-value $=0.0043$. C) Soluble levels of $\mathrm{A} \beta_{40}, r^{2}=0.0017, p$-value $\left.=0.80 . \mathrm{D}\right) \mathrm{Soluble}$ levels of $\mathrm{A} \beta 42, r^{2}=0.027, p$-value $=0.281$.

statistically significant correlation between MWM escape latency and $A \beta_{42} / A \beta_{40}$ ratio for any of these four additional mouse models. With only two APP(OSK)$\mathrm{Tg}$ data points, the correlation could not be assessed. The PS1 mice have an $r^{2}$ value of 0.10 and $p$-value of 0.60 . The $3 \times \mathrm{Tg}$ mice have an $r^{2}$ value of 0.072 and $p$ value of 0.73 . Finally, the APP mice have an $r^{2}$ value of 0.65 and $p$-value of 0.098 . Therefore, the specificity of mouse model type does not appear to explain the apparent absence of correlation between quantitative $\mathrm{A} \beta_{42} / \mathrm{A} \beta_{40}$ ratios and MWM escape latency.
Finding no consistent correlation between $\mathrm{A} \beta_{42} / \mathrm{A} \beta_{40}$ ratio and $\mathrm{MWM}$ escape latency in our systematic review of the five examined transgenic mouse models, we subsequently examined a different measure of cognitive function in transgenic $\mathrm{AD}$ mice-exploratory preference percentage in the NOR test. Data for the NOR test was pooled and systematically reviewed from $8 \mathrm{Tg} 2576$ mouse articles. However, our statistical assessment of the combined NOR set of 19 data points reveals no statistically significant correlation between exploratory preference 

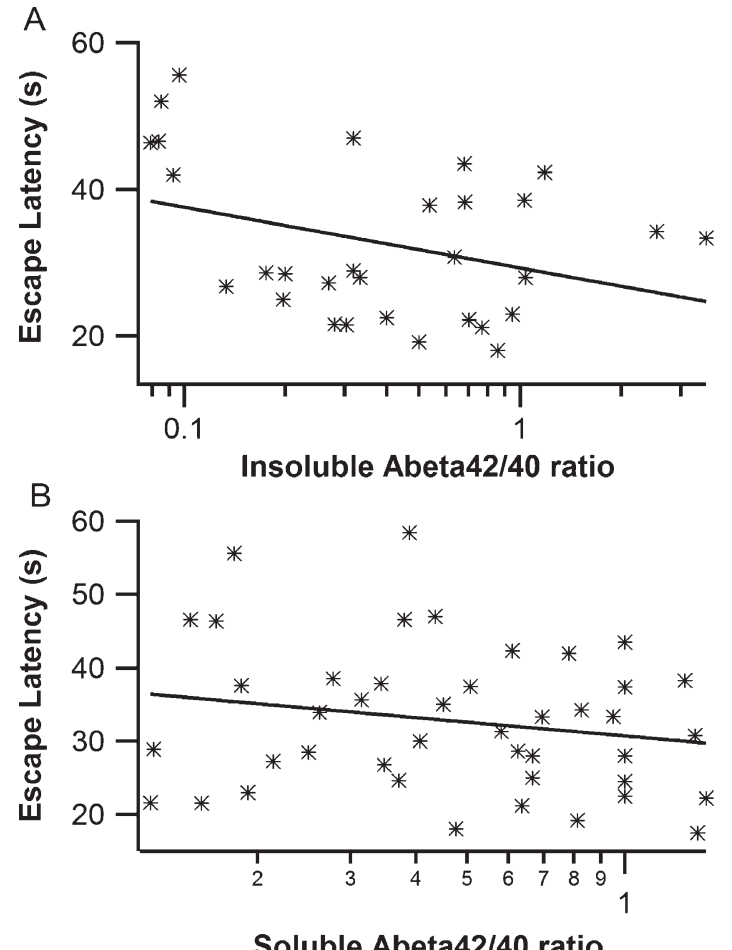

Fig. 2. Extracted and pooled $\mathrm{Tg} 2576$ data from 21 studies showed no statistical correlation between Morris water maze escape latency and the $\log$ of $A \beta_{42}$ to $A \beta_{40}$ ratio in the brain tissue of transgenic mice. A) soluble ratio between levels of $\mathrm{A} \beta_{42}$ to $\mathrm{A} \beta_{40}, r^{2}=0.039$, $p$-value $=0.206$. B insoluble ratio, $r^{2}=0.118, p$-value $=0.0625$.

percentage and $A \beta_{42}$ to $A \beta_{40}$ ratio, as the $r^{2}$ value was 0.079 and the $p$-value was 0.24 (Fig. 5).

\section{DISCUSSION}

The results for our systematic review of 40 different transgenic AD mouse research articles showed no reliable correlation between $A \beta$ levels $\left(A \beta_{40}, A \beta_{42}\right.$, and $\left.A \beta_{42} / A \beta_{40}\right)$ and experimental assessments of $\operatorname{cog}$ nitive function (maze escape latency or exploratory preference percentage). Despite examining results from two different cognitive tests (MWM and NOR), five different mouse models (Tg2576, APP, PS1, 3xTg, and $\mathrm{APP}(\mathrm{OSK})-\mathrm{Tg})$ and considering potential gender and age differences, no statistical relationship could be identified linking $A \beta$ to mouse cognitive decline in $\mathrm{AD}$. However, enough of the trends were of the same sign to suggest that there probably is a very weak qualitative trend visible only across many orders of magnitude. In summary, the results of the systematic review revealed that mice bred to show elevated levels of $A \beta$ do not perform significantly worse in cog-
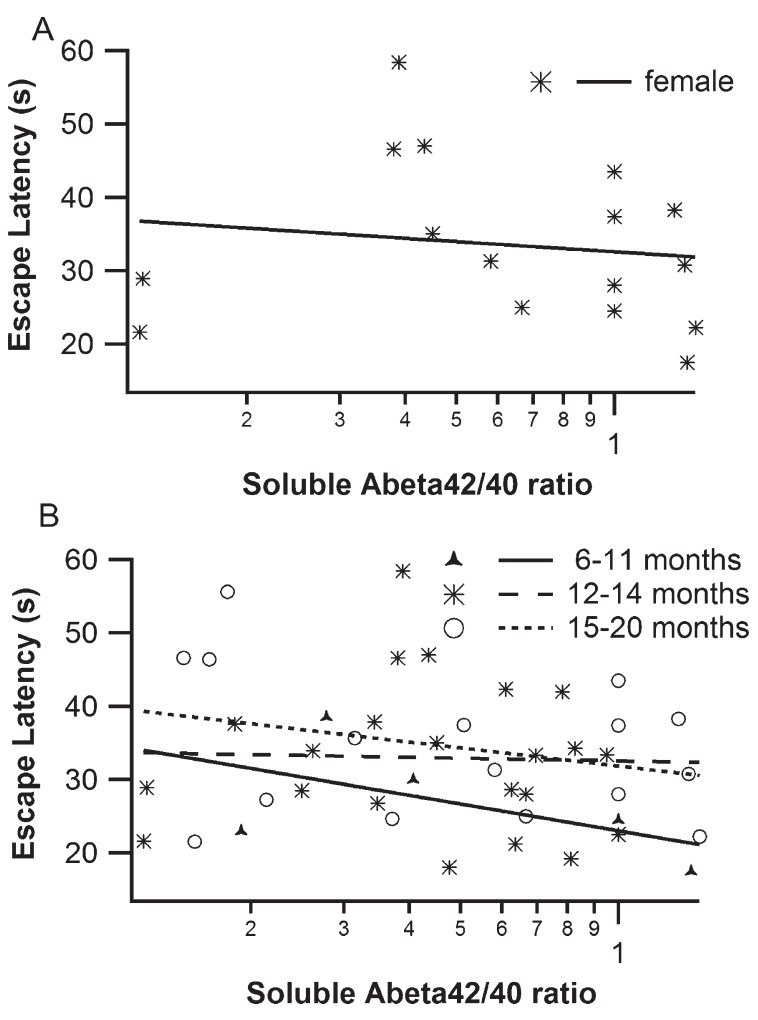

Fig. 3. Age and Gender Separation data showed no statistical correlation between Morris water maze escape latency and the log of $A \beta_{42}$ to $A \beta_{40}$ ratio in the brain tissue of transgenic mice. Extracted data for the $\mathrm{Tg} 2576$ mice were separated into groups based on age and gender differences used in the included studies. A) All female mice, $r^{2}=0.02, p$-value $=0.6$. B) Mice ages 6-11 months, $r^{2}=0.31$, $p$-value $=0.33$. Mice ages $12-14$ months, $r^{2}=0.001, p$-value $=0.88$. Mice ages 15-20 months, $r^{2}=0.093, p$-value $=0.25$.

nitive tests than mice that do not have elevated $A \beta$ levels.

It is possible that a particular mouse model or experimental cognitive function assessment combination not examined as part of this systematic review may reveal a correlation between $\mathrm{A} \beta$ and $\mathrm{AD}$ cognitive decline. However, given the size and statistical power of the data sets examined, we propose two more likely hypotheses to explain the lack of correlation between elevated quantitative $A \beta$ levels and poor cognitive performance: 1) Learning and memory deficits in $A D$ are tied to the presence of qualitatively "high" levels of A $\beta$ but are not quantitatively sensitive to the numerical values of the levels, themselves; or 2) It is possible that $A \beta$, itself, is not directly responsible for AD-related cognitive impairment, but rather is simply a "side effect" of the ongoing biochemical and cellular processes involved in the AD pathology. 

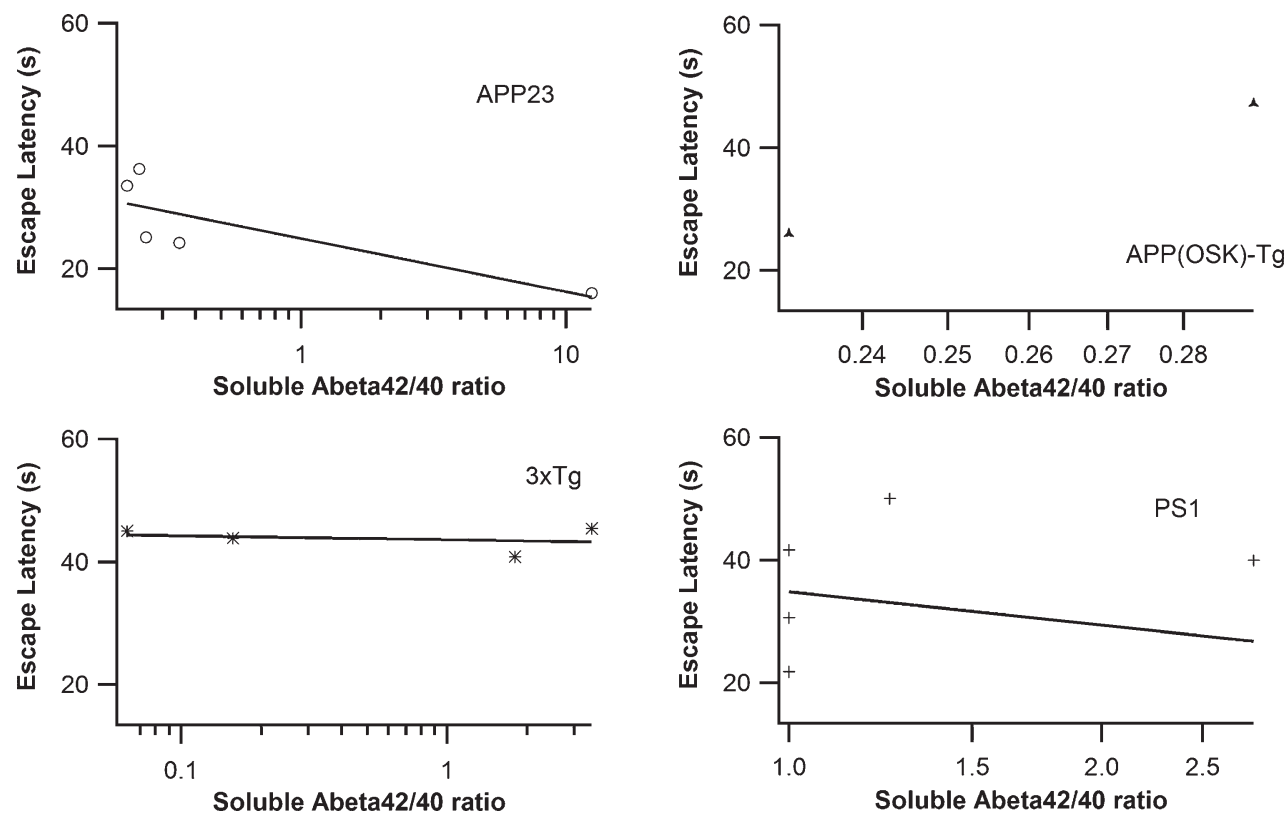

Fig. 4. APP, APP(OSK)-Tg, $3 \times \mathrm{Tg}$, and PS1 mice showed no correlation between Morris water maze escape latency and the log of $\mathrm{A} \beta_{42}$ to $\mathrm{A} \beta_{40}$ ratio in brain tissue. Extracted data for A) APP mice, $r^{2}=0.65, p$-value $=0.098$. B) $\mathrm{APP}(\mathrm{OSK})$-Tg mice, too few points. C) $3 \times \mathrm{xg}$ mice, $r^{2}=0.072, p$-value $=0.73$. D) PS1 mice, $r^{2}=0.10, p$-value $=0.60$.

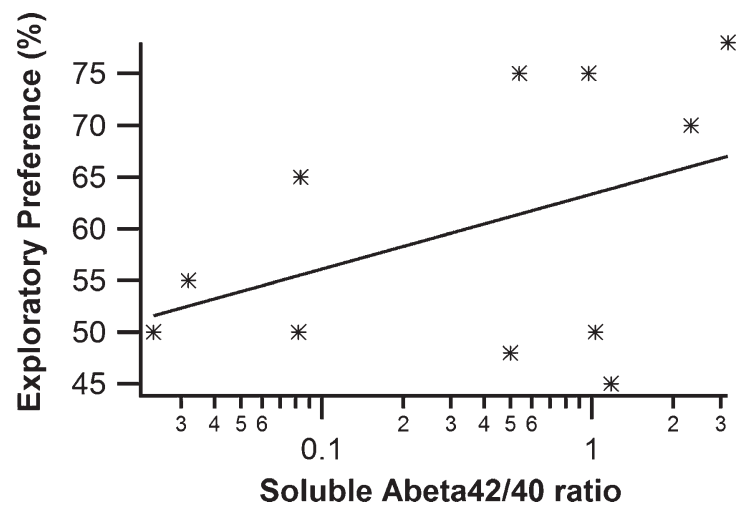

Fig. 5. Extracted data for Tg2576 mice subjected to the novel object recognition test showed no correlation between exploratory preference percentage and the $\log A \beta_{42}$ to $A \beta_{40}$ ratio in brain tissue, $r^{2}=0.19, p$-value $=0.19$.

In fact, more recent research has cited evidence against the Amyloid Cascade Hypothesis. One of the most cited points against the Amyloid Cascade Hypothesis is that, after more than two decades of research, not a single viable treatment for $\mathrm{AD}$ has resulted from treatments based on this hypothesis [20, 26-28]. Another point made against the Amyloid hypothesis is that while $A \beta$ levels are often elevated among AD patients [29], the levels, themselves, are not consistent indicators of clinical AD advancement and progression among individuals $[5,30]$. In fact, in some studies, several AD patients who had severely deteriorated memory showed no plaques postmortem $[5,26-28,30,31]$. While transgenic mouse experimental correlations are helpful for understanding disease mechanisms, they should not be misunderstood as "clinical" correlations. Nonetheless, despite the fact that the sporadic forms of clinical AD do not share the same underlying genetics of AD mice, an examination of quantitative $A \beta$ levels in comparison to cognitive function appears to be the similar; that is, in both human AD patients and transgenic mouse models, there is a lack of a direct, quantitative correlation between $A \beta$ levels and cognitive performance.

Furthermore, it has been proposed that decline in brain metabolic activity, which is tightly linked to synaptic activity, actually underlies both the cognitive decline in $\mathrm{AD}$ and the deposition of $\mathrm{A} \beta$ [23]. The fact that vast overproduction of $A \beta$ peptides in the brain of transgenic mouse models fails to cause overt neurodegeneration raises the question as to whether accumulation of $A \beta$ peptides is indeed the primary culprit for neurodegeneration in $\mathrm{AD}$ [24]. There is increasing evidence to suggest that A $\beta$ /amyloid-independent factors, including the actions of AD-related genes (microtubule-associated protein tau, polymorphisms of apolipoprotein E4), inflammation, and oxidative stress, also contribute to $\mathrm{AD}$ pathogenesis $[32,33]$. Thus, while no one argues that 
$\mathrm{A} \beta$ accumulation is present in both clinical $\mathrm{AD}$ and $\mathrm{AD}$ transgenic mice, $\mathrm{A} \beta$ accumulation, itself, may not directly result in associated cognitive decline. The results of this large systematic review of AD transgenic mouse data, in conjunction with the aforementioned research, support the contention that the debate over the possible role of $\mathrm{A} \beta$ in $\mathrm{AD}$ cognitive decline needs to be re-ignited and fueled by research into other possible hypotheses and explanations.

\section{ACKNOWLEDGMENTS}

This study was funded by National Institute of Health grants NS081426 and NS069616 to CSM. The funding agency had no role in the design and conduct of the study, collection, management analysis, and interpretation of the data; preparation, review, or approval of the manuscript; or decision to submit the manuscript for publication.

Authors' disclosures available online (http://www.jalz.com/disclosures/view.php?id=2565).

\section{REFERENCES}

[1] Reitz C (2012) Alzheimer's disease and the amyloid cascade hypothesis: A critical review. Int J Alzheimers Dis 2012, 369808.

[2] Tayeb HO, Murray ED, Price BH, Tarazi FI (2013) Bapineuzumab and solanezumab for Alzheimer's disease: Is the 'amyloid cascade hypothesis' still alive? Expert Opin Biol Ther 13, 1075-1084.

[3] Fast R, Rodell A, Gjedde A, Mouridsen K, Alstrup AK, Bjarkam CR, West MJ, Berendt M, Moller A (2013) PiB fails to map amyloid deposits in cerebral cortex of aged dogs with canine cognitive dysfunction. Front Aging Neurosci 5, 99.

[4] Hardy J, Allsop D (1991) Amyloid deposition as the central event in the aetiology of Alzheimer's disease. Trends Pharmacol Sci 12, 383-388.

[5] Hardy J, Selkoe DJ (2002) The amyloid hypothesis of Alzheimer's disease: Progress and problems on the road to therapeutics. Science 297, 353-356.

[6] Simon AM, Frechilla D, del Rio J (2010) [Perspectives on the amyloid cascade hypothesis of Alzheimer's disease]. Rev Neurol 50, 667-675.

[7] Lim YY, Maruff P, Pietrzak RH, Ellis KA, Darby D, Ames D, Harrington K, Martins RN, Masters CL, Szoeke C, Savage G, Villemagne VL, Rowe CC, Group AR (2014) Abeta and cognitive change: Examining the preclinical and prodromal stages of Alzheimer's disease. Alzheimers Dement, doi: 10.1016/j.jalz.2013.11.005.

[8] Pirttimaki TM, Codadu NK, Awni A, Pratik P, Nagel DA, Hill EJ, Dineley KT, Parri HR (2013) alpha7 Nicotinic receptormediated astrocytic gliotransmitter release: Abeta effects in a preclinical Alzheimer's mouse model. PLoS One 8, e81828.

[9] Westerman MA, Cooper-Blacketer D, Mariash A, Kotilinek L, Kawarabayashi T, Younkin LH, Carlson GA, Younkin SG, Ashe KH (2002) The relationship between Abeta and memory in the $\mathrm{Tg} 2576$ mouse model of Alzheimer's disease. J Neurosci 22, 1858-1867.
[10] Holcomb L, Gordon MN, McGowan E, Yu X, Benkovic S, Jantzen P, Wright K, Saad I, Mueller R, Morgan D, Sanders S, Zehr C, O'Campo K, Hardy J, Prada CM, Eckman C, Younkin S, Hsiao K, Duff K (1998) Accelerated Alzheimer-type phenotype in transgenic mice carrying both mutant amyloid precursor protein and presenilin 1 transgenes. Nat Med 4, 97-100.

[11] Sutherland RJ, Whishaw IQ, Regehr JC (1982) Cholinergic receptor blockade impairs spatial localization by use of distal cues in the rat. J Comp Physiol Psychol 96, 563-573.

[12] Antunes M, Biala G (2012) The novel object recognition memory: Neurobiology, test procedure, and its modifications. Cogn Process 13, 93-110.

[13] Sauvee M, Didierlaurent G, Latarche C, Escanye MC, Olivier JL, Malaplate-Armand C (2014) Additional use of Abeta42/Abeta40 ratio with cerebrospinal fluid biomarkers ptau and Abeta42 increases the level of evidence of Alzheimer's disease pathophysiological process in routine practice. J Alzheimers Dis 41, 377-386.

[14] Murray MM, Bernstein SL, Nyugen V, Condron MM, Teplow DB, Bowers MT (2009) Amyloid beta protein: Abeta40 inhibits Abeta42 oligomerization. J Am Chem Soc 131, 6316-6317.

[15] Lim YY, Maruff P, Pietrzak RH, Ames D, Ellis KA, Harrington K, Lautenschlager NT, Szoeke C, Martins RN, Masters CL, Villemagne VL, Rowe CC, Group AR (2014) Effect of amyloid on memory and non-memory decline from preclinical to clinical Alzheimer's disease. Brain 137, 221-231.

[16] Sorrentino P, Iuliano A, Polverino A, Jacini F, Sorrentino $\mathrm{G}$ (2014) The dark sides of amyloid in Alzheimer's disease pathogenesis. FEBS Lett 588, 641-652.

[17] Drachman DA (2014) The amyloid hypothesis, time to move on: Amyloid is the downstream result, not cause, of Alzheimer's disease. Alzheimers Dement 10, 372-380.

[18] Krstic D, Knuesel I (2013) The airbag problem-a potential culprit for bench-to-bedside translational efforts: Relevance for Alzheimer's disease. Acta Neuropathol Commun 1, 62.

[19] McGeer PL, McGeer EG (2013) The amyloid cascadeinflammatory hypothesis of Alzheimer disease: Implications for therapy. Acta Neuropathol 126, 479-497.

[20] Robakis NK (2011) Mechanisms of AD neurodegeneration may be independent of Abeta and its derivatives. Neurobiol Aging 32, 372-379.

[21] Van Dam D, Vloeberghs E, Abramowski D, Staufenbiel M, De Deyn PP (2005) APP23 mice as a model of Alzheimer's disease: An example of a transgenic approach to modeling a CNS disorder. CNS Spectr 10, 207-222.

[22] Umeda T, Tomiyama T, Kitajima E, Idomoto T, Nomura S, Lambert MP, Klein WL, Mori H (2012) Hypercholesterolemia accelerates intraneuronal accumulation of Abeta oligomers resulting in memory impairment in Alzheimer's disease model mice. Life Sci 91, 1169-1176.

[23] Lok K, Zhao H, Shen H, Wang Z, Gao X, Zhao W, Yin M (2013) Characterization of the APP/PS1 mouse model of Alzheimer's disease in senescence accelerated background. Neurosci Lett 557 (Pt B), 84-89.

[24] Sterniczuk R, Antle MC, Laferla FM, Dyck RH (2010) Characterization of the 3xTg-AD mouse model of Alzheimer's disease: Part 2. Behavioral and cognitive changes. Brain Res 1348, 149-155.

[25] Vorhees CV, Williams MT (2006) Morris water maze: Procedures for assessing spatial and related forms of learning and memory. Nat Protoc 1, 848-858.

[26] Balin BJ, Hudson AP (2014) Etiology and pathogenesis of late-onset Alzheimer's disease. Curr Allergy Asthma Rep 14, 417. 
[27] Nalivaeva NN, Turner AJ (2013) The amyloid precursor protein: A biochemical enigma in brain development, function and disease. FEBS Lett 587, 2046-2054.

[28] Pimplikar SW, Nixon RA, Robakis NK, Shen J, Tsai LH (2010) Amyloid-independent mechanisms in Alzheimer's disease pathogenesis. J Neurosci 30, 14946-14954.

[29] Chang YJ, Chen YR (2014) The co-existence of an equal amount of Alzheimer's amyloid-beta 40 and 42 forms structurally stable and toxic oligomers through a distinct pathway. FEBS J 281, 2674-2687.

[30] Pimplikar SW (2009) Reassessing the amyloid cascade hypothesis of Alzheimer's disease. Int J Biochem Cell Biol 41, 1261-1268.

[31] Hou L, Lee HG, Han F, Tedesco JM, Perry G, Smith MA, Zagorski MG (2013) Modification of amyloid-beta1-42 fibril structure by methionine-35 oxidation. J Alzheimers Dis $\mathbf{3 7}$, 9-18.

[32] Struble RG, Ala T, Patrylo PR, Brewer GJ, Yan XX (2010) Is brain amyloid production a cause or a result of dementia of the Alzheimer's type? J Alzheimers Dis 22, 393-399.

[33] Skaper SD (2012) Alzheimer's disease and amyloid: Culprit or coincidence? Int Rev Neurobiol 102, 277-316.

[34] Chang WP, Huang X, Downs D, Cirrito JR, Koelsch G, Holtzman DM, Ghosh AK, Tang J (2011) Beta-secretase inhibitor GRL-8234 rescues age-related cognitive decline in APP transgenic mice. FASEB J 25, 775-784.

[35] Wang J, Ho L, Zhao W, Ono K, Rosensweig C, Chen L, Humala N, Teplow DB, Pasinetti GM (2008) Grape-derived polyphenolics prevent Abeta oligomerization and attenuate cognitive deterioration in a mouse model of Alzheimer's disease. J Neurosci 28, 6388-6392.

[36] Toda T, Noda Y, Ito G, Maeda M, Shimizu T (2011) Presenilin2 mutation causes early amyloid accumulation and memory impairment in a transgenic mouse model of Alzheimer's disease. J Biomed Biotechnol 2011, 617974

[37] Ohno M, Chang L, Tseng W, Oakley H, Citron M, Klein WL, Vassar R, Disterhoft JF (2006) Temporal memory deficits in Alzheimer's mouse models: Rescue by genetic deletion of BACE1. Eur J Neurosci 23, 251-260.

[38] Chauhan NB, Sandoval J (2007) Amelioration of early cognitive deficits by aged garlic extract in Alzheimer's transgenic mice. Phytother Res 21, 629-640.

[39] Manso Y, Carrasco J, Comes G, Meloni G, Adlard PA, Bush AI, Vasak M, Hidalgo J (2012) Characterization of the role of metallothionein-3 in an animal model of Alzheimer's disease. Cell Mol Life Sci 69, 3683-3700.

[40] Peng CX, Hu J, Liu D, Hong XP, Wu YY, Zhu LQ, Wang JZ (2013) Disease-modified glycogen synthase kinase-3beta intervention by melatonin arrests the pathology and memory deficits in an Alzheimer's animal model. Neurobiol Aging 34, 1555-1563.

[41] Jeong YH, Kim JM, Yoo J, Lee SH, Kim HS, Suh YH (2011) Environmental enrichment compensates for the effects of stress on disease progression in $\mathrm{Tg} 2576$ mice, an Alzheimer's disease model. J Neurochem 119, 1282-1293.

[42] Parachikova A, Green KN, Hendrix C, LaFerla FM (2010) Formulation of a medical food cocktail for Alzheimer's disease: Beneficial effects on cognition and neuropathology in a mouse model of the disease. PLoS One 5, e14015.

[43] Mouri A, Noda Y, Hara H, Mizoguchi H, Tabira T, Nabeshima $\mathrm{T}$ (2007) Oral vaccination with a viral vector containing Abeta cDNA attenuates age-related Abeta accumulation and memory deficits without causing inflammation in a mouse Alzheimer model. FASEB J 21, 2135-2148.
[44] Hartman RE, Shah A, Fagan AM, Schwetye KE, Parsadanian M, Schulman RN, Finn MB, Holtzman DM (2006) Pomegranate juice decreases amyloid load and improves behavior in a mouse model of Alzheimer's disease. Neurobiol Dis 24, 506-515.

[45] Stackman RW, Eckenstein F, Frei B, Kulhanek D, Nowlin J, Quinn JF (2003) Prevention of age-related spatial memory deficits in a transgenic mouse model of Alzheimer's disease by chronic Ginkgo biloba treatment. Exp Neurol 184, 510-520.

[46] Rasool S, Albay R, 3rd, Martinez-Coria H, Breydo L, Wu J, Milton S, Misra S, Tran A, Pensalfini A, Laferla F, Kayed R, Glabe CG (2012) Vaccination with a non-human random sequence amyloid oligomer mimic results in improved cognitive function and reduced plaque deposition and micro hemorrhage in Tg2576 mice. Mol Neurodegener 7, 37.

[47] Zou J, Yao Z, Zhang G, Wang H, Xu J, Yew DT, Forster EL (2008) Vaccination of Alzheimer's model mice with adenovirus vector containing quadrivalent foldable Abeta(1-15) reduces Abeta burden and behavioral impairment without Abeta-specific T cell response. J Neurol Sci 272, 87-98.

[48] Soumyanath A, Zhong YP, Henson E, Wadsworth T, Bishop J, Gold BG, Quinn JF (2012) Centella asiatica extract improves behavioral deficits in a mouse model of Alzheimer's disease: Investigation of a possible mechanism of action. Int $J$ Alzheimers Dis 2012, 381974.

[49] Quinn JF, Bussiere JR, Hammond RS, Montine TJ, Henson E, Jones RE, Stackman RW, Jr. (2007) Chronic dietary alphalipoic acid reduces deficits in hippocampal memory of aged Tg2576 mice. Neurobiol Aging 28, 213-225.

[50] Quinn JF, Harris CJ, Cobb KE, Domes C, Ralle M, Brewer G, Wadsworth TL (2010) A copper-lowering strategy attenuates amyloid pathology in a transgenic mouse model of Alzheimer's disease. J Alzheimers Dis 21, 903-914.

[51] Gerenu G, Dobarro M, Ramirez MJ, Gil-Bea FJ (2013) Early cognitive stimulation compensates for memory and pathological changes in Tg2576 mice. Biochim Biophys Acta $\mathbf{1 8 3 2}$, 837-847.

[52] Mitchell JC, Perkinton MS, Yates DM, Lau KF, Rogelj B, Miller CC, McLoughlin DM (2010) Expression of the neuronal adaptor protein X11alpha protects against memory dysfunction in a transgenic mouse model of Alzheimer's disease. J Alzheimers Dis 20, 31-36.

[53] Murakami K, Murata N, Noda Y, Tahara S, Kaneko T, Kinoshita N, Hatsuta H, Murayama S, Barnham KJ, Irie K, Shirasawa T, Shimizu T (2011) SOD1 (copper/zinc superoxide dismutase) deficiency drives amyloid beta protein oligomerization and memory loss in mouse model of Alzheimer disease. J Biol Chem 286, 44557-44568.

[54] Lee EB, Leng LZ, Zhang B, Kwong L, Trojanowski JQ, Abel T, Lee VM (2006) Targeting amyloid-beta peptide (Abeta) oligomers by passive immunization with a conformation-selective monoclonal antibody improves learning and memory in Abeta precursor protein (APP) transgenic mice. J Biol Chem 281, 4292-4299.

[55] Mitchell JC, Ariff BB, Yates DM, Lau KF, Perkinton MS, Rogelj B, Stephenson JD, Miller CC, McLoughlin DM (2009) $\mathrm{X} 11$ beta rescues memory and long-term potentiation deficits in Alzheimer's disease APPswe Tg2576 mice. Hum Mol Genet 18, 4492-4500.

[56] Saura CA, Chen G, Malkani S, Choi SY, Takahashi RH, Zhang D, Gouras GK, Kirkwood A, Morris RG, Shen J (2005) Conditional inactivation of presenilin 1 prevents amyloid accumulation and temporarily rescues contextual and spatial working memory impairments in amyloid precursor protein transgenic mice. J Neurosci 25, 6755-6764. 
[57] Terwel D, Steffensen KR, Verghese PB, Kummer MP, Gustafsson JA, Holtzman DM, Heneka MT (2011) Critical role of astroglial apolipoprotein $\mathrm{E}$ and liver $\mathrm{X}$ receptor-alpha expression for microglial Abeta phagocytosis. J Neurosci 31, 7049-7059.

[58] Lefterov I, Fitz NF, Cronican A, Lefterov P, Staufenbiel M, Koldamova R (2009) Memory deficits in APP23/Abca1+/mice correlate with the level of Abeta oligomers. ASN Neuro 1, pii: e00006.

[59] Minkeviciene R, Ihalainen J, Malm T, Matilainen O, KeksaGoldsteine V, Goldsteins G, Iivonen H, Leguit N, Glennon J, Koistinaho J, Banerjee P, Tanila H (2008) Age-related decrease in stimulated glutamate release and vesicular glutamate transporters in APP/PS1 transgenic and wild-type mice. J Neurochem 105, 584-594.

[60] Oksman M, Iivonen H, Hogyes E, Amtul Z, Penke B, Leenders I, Broersen L, Lutjohann D, Hartmann T, Tanila H (2006) Impact of different saturated fatty acid, polyunsaturated fatty acid and cholesterol containing diets on beta-amyloid accumulation in APP/PS1 transgenic mice. Neurobiol Dis $\mathbf{2 3}$, 563-572.

[61] Lewis TL, Cao D, Lu H, Mans RA, Su YR, Jungbauer L, Linton MF, Fazio S, LaDu MJ, Li L (2010) Overexpression of human apolipoprotein A-I preserves cognitive function and attenuates neuroinflammation and cerebral amyloid angiopathy in a mouse model of Alzheimer disease. J Biol Chem 285, 36958-36968.

[62] Wang CY, Wang T, Zheng W, Zhao BL, Danscher G, Chen YH, Wang ZY (2010) Zinc overload enhances APP cleavage and Abeta deposition in the Alzheimer mouse brain. PLoS One 5, e15349.

[63] Clinton LK, Billings LM, Green KN, Caccamo A, Ngo J, Oddo S, McGaugh JL, LaFerla FM (2007) Age-dependent sexual dimorphism in cognition and stress response in the 3xTg-AD mice. Neurobiol Dis 28, 76-82.

[64] Minami SS, Clifford TG, Hoe HS, Matsuoka Y, Rebeck GW (2012) Fyn knock-down increases Abeta, decreases phospho-tau, and worsens spatial learning in 3xTg-AD mice. Neurobiol Aging 33, 825 e815-824.

[65] Cao C, Arendash GW, Dickson A, Mamcarz MB, Lin X, Ethell DW (2009) Abeta-specific Th2 cells provide cognitive and pathological benefits to Alzheimer's mice without infiltrating the CNS. Neurobiol Dis 34, 63-70.

[66] Canas PM, Porciuncula LO, Cunha GM, Silva CG, Machado NJ, Oliveira JM, Oliveira CR, Cunha RA (2009) Adenosine A2A receptor blockade prevents synaptotoxicity and memory dysfunction caused by beta-amyloid peptides via p38 mitogen-activated protein kinase pathway. J Neurosci $\mathbf{2 9}$, 14741-14751.

[67] Cao Y, Xiao Y, Ravid R, Guan ZZ (2010) Changed clathrin regulatory proteins in the brains of Alzheimer's disease patients and animal models. J Alzheimers Dis 22, 329-342.

[68] Capsoni S, Amato G, Vignone D, Criscuolo C, Nykjaer A, Cattaneo A (2013) Dissecting the role of sortilin receptor signaling in neurodegeneration induced by NGF deprivation. Biochem Biophys Res Commun 431, 579-585.

[69] Cai Z, Zhao Y, Yao S, Bin Zhao B (2011) Increases in beta-amyloid protein in the hippocampus caused by diabetic metabolic disorder are blocked by minocycline through inhibition of NF-kappaB pathway activation. Pharmacol Rep 63, 381-391.

[70] Cao D, Fukuchi K, Wan H, Kim H, Li L (2006) Lack of LDL receptor aggravates learning deficits and amyloid deposits in Alzheimer transgenic mice. Neurobiol Aging 27, 1632-1643.

[71] Cacucci F, Yi M, Wills TJ, Chapman P, O'Keefe J (2008) Place cell firing correlates with memory deficits and amyloid plaque burden in Tg2576 Alzheimer mouse model. Proc Natl Acad Sci U S A 105, 7863-7868.

[72] Capsoni S, Carlo AS, Vignone D, Amato G, Criscuolo C, Willnow TE, Cattaneo A (2013) SorLA deficiency dissects amyloid pathology from tau and cholinergic neurodegeneration in a mouse model of Alzheimer's disease. J Alzheimers Dis 33, 357-371. 